\title{
- Estado del conocimiento de las competencias digitales
}

\author{
State of knowledge of digital competences \\ Yeny Jiménez Izquierdo ${ }^{1 *}$, Joel Angulo Armenta², Rigoberto García Cupil , David López Ordoñez ${ }^{4}$ \\ y Raúl Teno Sánchez ${ }^{5}$
}

${ }^{1,5}$ División Académica de Ciencias Sociales y Humanidades, Universidad Juárez Autónoma de Tabasco, México, ${ }^{2}$ Departmento de Educación, Instituto Tecnológico de Sonora, México, ${ }^{3}$ División Académica de Educación y Artes, Universidad Juárez Autónoma de Tabasco, México, ${ }^{4}$ Sistema de Educación a Distancia, Universidad Juárez Autónoma de Tabasco,

México

*Autora a quien se dirige la correspondencia: yenyj@hotmail.com

Resumen

— $\mathrm{n}$ esta investigación se revisó el estado de conocimiento de la competencia digital en México y América Latina - durante los últimos nueve años, a fin de identificar los estudios de menor y mayor producción científica, enfoque metodológico, tipo de población, nivel educativo y áreas de oportunidad que requieren un conocimiento profundo sobre el fenómeno de interés. Se realizó bajo el enfoque exploratorio analítico mediante una búsqueda de literatura en artículos indexados, tesis doctorales y ponencias de eventos científicos. Se utilizaron las técnicas ficha de contenido y lista de verificación para la recopilación de los datos. De los hallazgos se infiere que 42 estudios cumplen los criterios de inclusión, España $(n=20)$ y México $(n=13)$ tienen una mayor producción científica, el método más utilizado es de tipo cuantitativo $(n=30)$, la mayoría de los estudios se orientan al estudiante universitario $(n=21)$, en general proponen instrumentos de medición y evaluación $(n=31)$ y son escasos los trabajos relacionados con estrategias de desarrollo de competencia digital $(\mathrm{N}=4)$. Finalmente, se concluye que aún prevalecen las investigaciones centradas en la evaluación de competencias digitales del estudiante universitario y pocos trabajos reportan una rigurosa metodología que demuestre validez y confiabilidad en los resultados obtenidos.

Palabras claves: Competencias digitales, docente, estudiante, formación, tecnologías de la información y comunicación

\begin{abstract}
$\mathrm{T}$ his research reviewed the state of knowledge of digital competence in Mexico and Latin America during the last nine years in order to identify studies of lower and higher scientific production, methodological approach, type of population and educational level and areas of opportunity require a thorough knowledge of the phenomenon of interest. It was carried out under the analytical exploratory approach through a search of literature in indexed articles, doctoral theses and papers of scientific events. The technical data sheet and checklist for data collection were used. Of the findings, 42 studies meet the inclusion criteria, Spain $(n=20)$ and Mexico $(n=13)$ have a higher scientific production, the most used method is quantitative type $(n=30)$, most $(n=21)$, in general they propose measurement and evaluation tools $(n=31)$ and there are few studies related to digital competence development strategies $(\mathrm{N}=4)$. Finally, it is concluded that the research focused on the evaluation of digital competences of the university student still prevails and few works report a rigorous methodology that demonstrates validity and reliability in the obtained results.
\end{abstract}

Key words: Digital competitions, teacher, student, training, ICT 